\title{
Fault Lines, Racial and Aesthetic: The National Arts Festival at Grahamstown ${ }^{1}$
}

\author{
BRYAN SCHMIDT
}

This article asks how theatre shapes civic space by examining the emergence of racial divides in the city of Grahamstown, South Africa, during the annual National Arts Festival (NAF). I track how decision making by festival organizers has relied on economic research and implicit artistic preferences that have resulted in the steady exclusion of artists from local townships. I argue that the presence of the NAF in Grahamstown creates fault lines that are not physical, but aesthetic, in nature, creating invisible boundaries that reward stage performances at the expense of street performances. I track a history of street performance at the NAF, with particular attention to its local mime tradition, to demonstrate how this axis of festivity was integral to developing the NAF's cultural cachet, but was systematically managed, policed or appropriated to fit organizers' image for Grahamstown at festival time. This work troubles aspirational narratives of creative and cultural industries that South Africa and other African countries have come to rely upon as inclusive and sustainable routes of economic development.

It is true that if care is taken to use only a language that is understood by graduates in law and economics, you can easily prove that the masses have to be managed from above

Frantz Fanon, The Wretched of the Earth

The National Arts Festival (NAF) in Grahamstown, South Africa, publicizes itself as the largest annual arts event on the African continent, and a major driver of the local and regional economy. A 2017 economic-impact study estimates that the festival contributes R94.4 million (about \$7 million) to the local area annually, and about $\mathrm{R}_{377.15}$ million (\$25.36 million) to the Eastern Cape province. ${ }^{2}$ The NAF curates a Main Festival programme featuring some of the biggest names in South African theatre, dance and music, and provides infrastructure for an even larger festival fringe where non-sponsored artists pay their own way to perform in front of an arts-oriented crowd similar to international festivals in Edinburgh or Avignon. Each year, for '11 Days of Amazing' (the festival's tagline), artists and enthusiasts from across South Africa converge on tiny Grahamstown to transform it into a vast arts 'hypermarket', where seemingly every building becomes a venue for creative culture from sculpture to stand-up comedy. ${ }^{3}$

But Francois Knoetze's 2013 performance Cape Mongo did not take place in one of the many venues peppered throughout town. Instead, he donned a giant 
antelope-shaped suit made of cardboard detritus (mongo is slang for an object thrown away and then recovered) and pranced through Grahamstown's streets, silently approaching individuals, hunkering down and 'using body language and gestures' to provoke reactions (see Fig. 1). ${ }^{4}$ He danced with and embraced a few people who welcomed his approach, but was playfully poked or pushed away by others when he got in their faces; some children reportedly followed the upcycled beast for kilometres, while others ran away in fear. ${ }^{5}$ Knoetze's idiosyncratic performance throughout the city's thoroughfares was improvised, informal and non-textual, but it was not without intentionality. Having grown up in Grahamstown - which sees its 70,000-person population nearly triple during the festival - Knoetze made a social commentary through his spatial choreography, carefully selecting which streets to go down, which people to talk to and which nooks and crannies to imbue with his unique flair.

He stayed away from the western side of the city that receives the majority of foot traffic during the festival thanks to the presence of Rhodes University, several major venues and the Village Green - the NAF's curated trading hub that provides security and entertainment to assist traders who can afford its high fees (who tend to be white or coloured people from South Africa's major cities). ${ }^{6}$ Instead, Knoetze began his ambulatory performance at Church Square, a densely packed flea market in the centre of town populated almost exclusively by black Xhosa-speaking traders who cannot afford a stall at the Village Green, and so sell clothes, knick-knacks, crafts and electronics at bargain prices. Instead of travelling west down High Street towards the big crowds of patrons shuffling between theatres, Knoetze meandered three kilometres east to Makana's Kop and the Ntaba Primary School in Rhini (the area comprising the townships of Fingo, Tantji, Hlalani Villa, Eluxolweni and Joza). ${ }^{7}$ In an interview, he explained that his geographic route commented on the city's segregated social dynamics during festival time:

Over the years I saw the festival gradually moving more and more to the Rhodes side of town (culminating in the move of the Village Green to Rhodes campus), alienating and excluding the (mostly black) working class locals of the town. The job opportunities that walked hand in hand with informal trade on the streets of the town also disappeared as laws were implemented limiting the areas where people were allowed to set up stalls and tents ... [A] cycle of exclusion has been spiraling for a number of years. My performance was an attempt to highlight the growing divide between the festival and Grahamstown east (the townships of Grahamstown). ${ }^{8}$

Knoetze's lively street performance highlights how the NAF's economic impact and carnival atmosphere materialize unevenly in Grahamstown. Residents of townships which are expansive areas of sub-economic housing on city fringes occupied almost exclusively by black Africans as the result of the continued legacy of colonial and apartheid segregation - walk long distances or pay for transport to travel to the city centre each day to hawk or busk on the streets. They stand to profit from their labour, but it is a pittance compared to the potential gains of shopowners in the centre of town, vendors at the Village Green, and even fringe artists who run successful shows. 


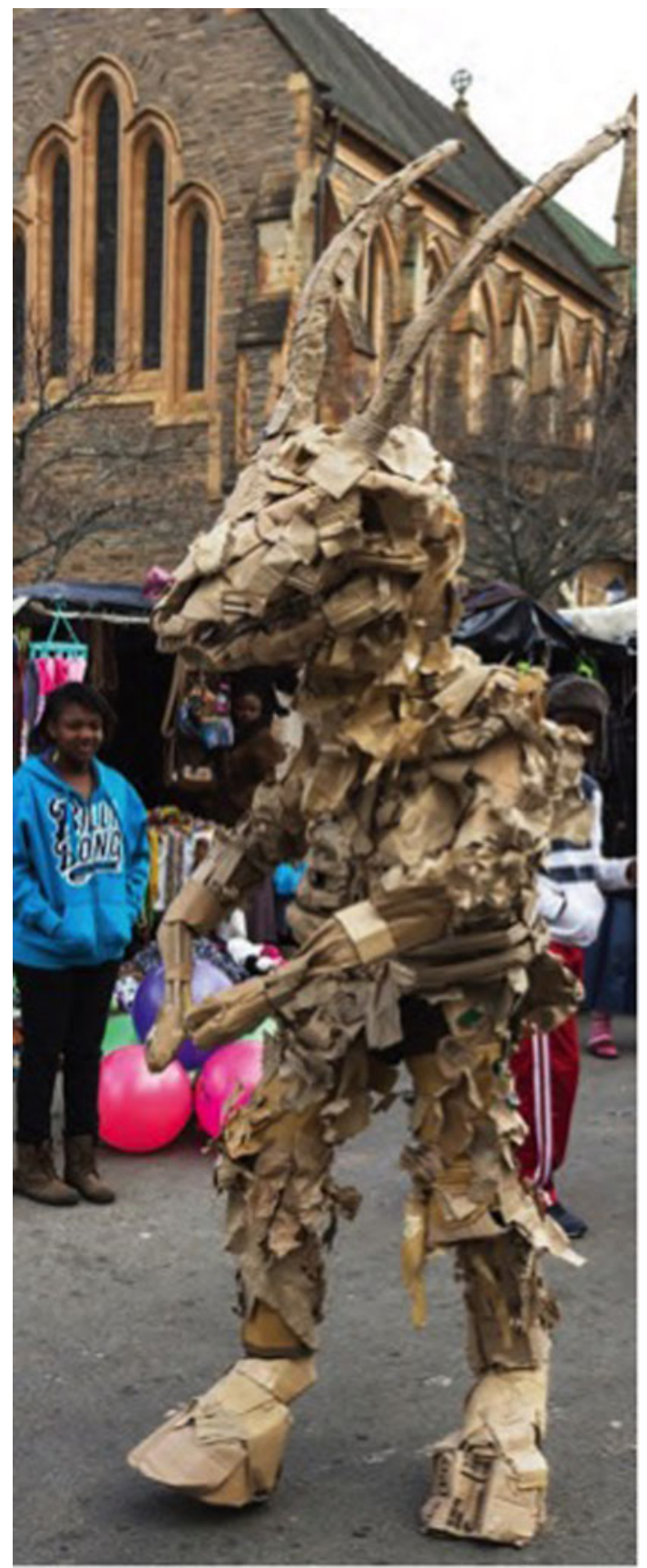

FIG. 1. Cape Mongo, Francois Knoetze (2013). Photograph by Cue magazine/Jason Cooper, 4 July 2013. 
This spatial divide creates one tier of artists, shops, traders and institutions who are well positioned to capitalize on the yearly influx of bodies into Grahamstown, and a secondary tier who stand to profit at only a marginal rate - an economic tiering that largely follows racial lines.

While the NAF has a storied place in the annals of South Africa's theatre culture, continued critical coverage of the event in theatre scholarship tends only to acknowledge a single dimension of festival activity: that of the stage. ${ }^{9}$ With Cape Mongo, Knoetze pointed to another axis of performance that has been equally, if not more, significant in building the NAF's unique cachet as a kueierfeeste, a festival of sociality: that of the street. ${ }^{10}$ Clad in the grotesquely rendered cardboard suit, he animated the grounds of Grahamstown east, creating a performance that operated as a free-form, mobile, environmental project, rather than a formal, enclosed artistic exhibition. The line he traced left little material residue, but produced a theatrical energy that martialled other bodies into motion around him. The kinetics prompted by this performance attested to a galvanizing public spectacle, but one that (much like the shards of cardboard detritus that comprised Knoetze's costume) simply fluttered into the wind; it was not a stable event with tickets, show posters, specific curtain times or an entry in the voluminous festival programme, but a contingent happening that left few measurable traces of its own existence. In this way, Cape Mongo cited an expansive tradition of improvised festive theatricality, while also calling attention to the relative disposability of this axis of performance. By appropriating the street as his stage, he highlighted the role that traders, buskers and other members of the informal economy (who often come from the city's townships) play in building the NAF's creative atmosphere - and their relative lack of recognition and financial remuneration.

The choreography of Cape Mongo illuminates fault lines that emerge in Grahamstown each year during festival time. These fault lines develop through the spatial arrangement of performances, and the ambience that materializes around them. They emerge also from particular logics of culture that create divisions within civic space, allowing economic benefits to flow towards some at the expense of others. In other words, these fault lines are not only material, but aesthetic, in nature. In the Western tradition, and alongside its more familiar connotation as the philosophy of art, beauty and taste, the field of aesthetics etymologically foregrounds sense and perception (from the Greek aesthêtikos: 'pertaining to sense perception'). ${ }^{11}$ Aesthetic fault lines are immaterial barriers that reflect the embodied experience of civic space, the invisible yet palpable divisions that arise through the production of an atmosphere, or 'vibe'. They contour how events create emotional energetics that overlie physical space, tacitly propelling people towards certain areas at the expense of others.

In this paper, I analyse how performance intersects with cultural policy and spatial politics to create racialized aesthetic fault lines in Grahamstown, which I illuminate by discussing the history of the NAF's street activities. The highly theatrical nature of the festival setting - especially in the small town of Grahamstown, where the NAF's creative activity becomes the central focal point of civic life for the festival's duration - allows these fault lines to become acutely visible for analysis. But such divisions exist in cities worldwide where arts and culture have come to take leading roles in 
economic development and urban branding. This is especially true in South Africa, where creative and cultural industries (CCIs in economics parlance) have been heralded as inclusive means of economic revitalization with the potential to reverse apartheid's legacy of economic exclusion. For instance, both the 1996 Arts and Culture White Paper and its 2017 update (crucial documents meant to guide arts organizations in the years following the end of apartheid) saw CCIs as priority areas for government support. These documents highlighted theatre and performance festivals specifically as events with the potential to provide work opportunities for artists, create larger audiences and arts markets, boost local economies and alleviate poverty, and serve as engines of 'sustainable development and cultural inclusion to the benefit of all who live in South Africa'. ${ }^{12}$ By critically interrogating the history of street performance at the NAF I consider how these social goals, coupled with the festival's own institutional priorities, have managed, policed and appropriated this creative dimension to the benefit of some, and at the expense of others. This study, then, uses theatre as a means to interrogate this aspirational model of cultural policy, and to consider its potential to contribute to a continued culture of segregation and economic exclusion.

\section{From Grahamstown to Makhanda: the NAF changes with the times}

In June 2018, the city of Grahamstown was officially renamed Makhanda. The renaming was the culmination of a decades-long effort towards symbolic reparation regarding South Africa's colonial past. Grahamstown was founded in 1820 as a British military outpost during the Xhosa Wars, and was named for the infamously brutal Colonel John Graham. The name Makhanda honours a Xhosa warrior, philosopher and prophet who led an attack on British forces at Grahamstown in 1819. In July 2018, the chief executive officer of the NAF, Tony Lankester, stated on the name change, 'South Africans tend to refer to us colloquially as the "Grahamstown Festival". I'm sure that, in time, the name "Makhanda Festival" will gain similar traction'. ${ }^{13}$ The temporal lag acknowledged here speaks to the powerful and enduring ways civic identity can be shaped by theatrical events, and poses a particular challenge to me in determining nomenclature for this article at this particular moment. In choosing to retain 'Grahamstown' for the purposes of this study I seek to render visible the myriad ways that the NAF has intersected with local and national politics over the last half-century: a relationship that has been particularly dynamic and often fraught.

The NAF began in 1974 as an English-language theatre and poetry celebration that coincided with the official opening of the 1820 Settlers National Monument in Grahamstown. The Settlers Monument was intended to exist as a living monument to commemorate the 150th anniversary of English colonizers landing in the Eastern Cape, housing the NAF as an annual celebration of anglophone settler heritage and culture. The NAF originally functioned as part of an array of festivals that used European artistic and cultural expositions to generate sympathy and support for the white supremacist project of apartheid, which lasted politically from 1948 to $1994 .{ }^{14}$ In the 1980s, the NAF became more liberal, but found itself in an increasingly embattled 
position. White and non-white anti-apartheid artists like Athol Fugard, Pieter-Dirk Uys, Yvonne Bryceland, Andrew Buckland, John Kani, Winston Ntshona and Zakes Mda famously used the festival to stage work protesting the government's escalating violence and successive states of emergency, which prompted the presence of uniformed, armed police, show cancellations and the arrest of performers. However, these plays tended to be performed to relatively uniform white audiences. The exclusion of black voices in festival management, and the increased police presence in Rhini during festival time, made the NAF a target for a cultural boycott promoted by the then-exiled African National Congress and the Mass Democratic Movement. Responding to pressure from these groups, as Kenneth Grundy reports it, in 1988 festival organizers 'opened a venue in the black township, [d]istributed free tickets to township residents (mostly through church leaders), and provided special bus services from the township to festival venues'. These moves, however, were not enough to assuage the Mass Democratic Movement, who believed that the NAF's limited association with the townships was merely a token gesture. ${ }^{15}$

After the transition to democracy in 1994, the NAF (like many other apartheid-era cultural organizations) instituted reforms aimed at radically integrating its staff, and developing social-responsibility and inclusion programmes to promote racial equity in the local area. Following a fire that year, the Settlers Monument was rededicated by then president Nelson Mandela, who called attention to its checkered history of exclusion, but placed faith in its ability to become 'a beacon for the future ... because it has so forcefully identified with change and the reconstruction of our country. ${ }^{16}$ Mandela positioned the Settlers Monument and, by extension, the NAF (which remains headquartered there) as bulwarks of a racially inclusive post-apartheid future.

The NAF's maintenance of its image as a positive institutional actor has been an important component of its ability to secure sponsorships and subsidies over the last two decades. When democracy replaced apartheid, it was accompanied by a turn to neo-liberal economic policy, which reverberated through arts organizations nationwide with an increased demand for technocratic managerial governance, the embrace of free-market capitalism, and an emphasis on empirical study of measurable economic outcomes. ${ }^{17}$ Today, the NAF is principally funded by Standard Bank; the South Africa Department of Arts and Culture; and the Eastern Cape Department of Sport, Recreation, Arts and Culture, which all justify their involvement by pointing to the festival's contribution to the local and regional economies. ${ }^{18}$ The South African Cultural Observatory (SACO) was formed in 2014 to achieve 'research outputs that would enhance the development of the [creative and culture industries] in South Africa [and] support the many policy imperatives of the [Department of Arts and Culture], the South African Government and its stakeholders'; its research has produced an extended picture of the NAF's contribution to Grahamstown by attributing to the festival positive intrinsic values like 'social cohesion', 'civic pride' and 'intercultural dialoguing', in addition to its financial outcomes. ${ }^{19}$

Since its inception the NAF has maintained a complex relationship with shifting political tides in South Africa, seeking to keep pace with change while also maintaining steady institutional growth by responding to sometimes contradictory 
demands from local citizens; trends in the wider arts marketplace; and the demand for measurable outcomes by national, regional and local governing bodies. The NAF has historically operated in both complicit and rebellious registers vis-à-vis apartheid, and in what follows I consider how these axes of social responsibility have shifted in the post-apartheid context. How do large-scale arts institutions participate in longitudinal projects of social control via the shaping of civic space, even as they seek to utilize art and the economic activity that flows from it as a form of social contribution?

\section{Race, stakeholdership and the politics of creative and cultural industries}

An example of a relatively recent way the NAF has attempted to demonstrate its institutional responsibility to Grahamstown's townships is through its sponsorship and promotion of the Fingo Festival, a five-day outdoor arts and education event that takes place in the middle of the NAF on the streets of Fingo Township. It began in 2011 through the work of community activists looking to ensure that proximate outlets existed for township residents to participate in the creative fervour that takes hold in Grahamstown during festival time. A large red tent houses the Fingo Festival, where residents pack in to see free kwaito (township hip-hop music), cultural dances, inspirational speakers and theatrical skits performed by troupes of young actors. Locals sometimes colloquially refer to the Fingo Festival as 'Five Days of Ama-Zing', a wordplay combining the NAF's tagline with the cadence of local Xhosa dialects, meant to communicate its existence as a black offshoot event. ${ }^{20}$

Rhini residents sometimes disagree over the event's value: organizers such as Xolile Madinda vigorously advocate for the Fingo Festival as a means of teaching 'black parents that art can be a way of life', and as a demonstration of the townships' capacity to build their own future, rather than working within the NAF's existing structure. ${ }^{21}$ Other activists argue that, by corralling residents to a small area on the east side of town, the Fingo Festival diminishes their capacity to envision themselves as part of the NAF itself; furthermore, it allows NAF organizers to avoid grappling with structural elements that exclude local residents from the events in the city centre, while still generating positive publicity for its own sponsorship (which amounted to less than $\$ 5,000$ in 2012). ${ }^{22}$

It is safe to say that the Fingo Festival is a product of Grahamstown's fault lines - a point that is not lost on the community. Each year, the event includes a conversation called 'Business beyond Festival' where residents discuss ways to parlay the activity brought to town by the NAF into ongoing economic opportunities for township residents. On 6 July 2017 I attended this conversation, which was billed as an opportunity for Rhini activists to dialogue with NAF CEO Tony Lankester. A number of proposals were suggested to help promote commerce on the east side of town: residents might offer donkey rides and township tours; they could provide guest-housing for out-of-towners; or they could create package heritage experiences around local landmarks associated with Lobengula, the last Ndebele king. ${ }^{23}$ Despite these suggestions, there was a pessimistic air in the room. Just as it was almost impossible to spot a single white person at the Fingo Festival, residents were sceptical 
that any initiative could actually lead significant numbers of tourists to integrate the townships into their NAF experience.

Acknowledging the frustration that little of the NAF's considerable economic impact flows to Rhini, Lankester placed blame on residents' insufficient utilization of infrastructure provided by the NAF to help them initiate their own business ventures: 'With all the people that come to town, if you can't find a way to make money, you're a bad entrepreneur'. ${ }^{24}$ Placing the onus on township residents to find their own way into the existing event structure, Lankester reinforced the image of the NAF as a responsible actor in post-apartheid South Africa: an institution run fairly and impartially, and one that might open space for the withering away of economic exclusion - so long as the local populace pulled its weight. Lankester deployed a neo-liberal discourse emphasizing personal responsibility and meritocratic principles dictated by marketplace demands. If township residents had not seen proportionate gains as the festival enjoyed continued success, the problem surely had to do with a failure of the community's work ethic and ingenuity, rather than a structural element of the event itself or the continuation of apartheid-era financial segregation.

Lankester's gesture towards inclusivity by participating in these conversations was overshadowed by a sense that the NAF's organizational decision making prioritized certain people and their modes of being-at-festival over others. A teaching artist named Asanti brought up this point when he provocatively asked Lankester, 'What criteria do you use for deciding the stakeholders in the community? ${ }^{25}$ The NAF has largely followed what we might call a 'festino-centric' approach to determining stakeholdership (from the South African colloquialism 'festino', meaning a festival patron). This approach prioritizes the needs and interests of paying customers who attend the NAF's shows, exhibitions and educational activities, seeing these particular forms of cultural consumption as the festival's thriving centre, which supports a secondary commercial and paratheatrical life that operates on the fringe. A typical example of this approach can be seen in the use of audience surveys as the preferred means for generating data on the NAF. Such surveys are handed out before or after patrons attend NAF showings, nominally designating these individuals as representatives for understanding how tourists and locals utilize Grahamstown during festival time.

But surveys are not handed out at the Fingo Festival. Nor are they handed out at the numerous free music and theatrical offerings that take place on street corners and storefronts, which organically gather audiences on impromptu bases. Asanti's question of stakeholdership subtly invoked aesthetic fault lines operating in Grahamstown by alluding to questions of visibility and invisibility that determine whom the organization prioritizes in its decision making. Could township residents be perceived by festival leaders as stakeholders in their own community, even if they lacked the financial means to patronize festival performances or pay for stall space at the Village Green? Who could be seen as an artist or patron, and who simply as a passive user of local space? Whose labour could be understood to enable festivity, and whose simply filled in the cracks?

Such questions of stakeholdership are especially important on the African continent, where theatre and arts festivals increasingly appear to policy makers as 
aspirational means to provide swift and sustainable economic growth, and to do so while utilizing heritage resources that are authentically and distinctly African. The African Union's 2006 Charter for African Cultural Renaissance, for instance, asserts that culture is 'the surest means to chart Africa's own course towards technological development, and the most efficient response to the challenges of globalization', as well as 'a factor of social progress and a driving force for innovation'. ${ }^{26}$ Merging the language of cultural exceptionalism with that of technocratic managerialism, it urges states to 'build the capacity of the cultural sector and stakeholders through the organization of festivals' and other creative activities. ${ }^{27}$ Likewise, South Africa's Mzansi Golden Economy Strategy figures art, culture and heritage as the country's 'new gold', and aims to 'reposition [these sectors] as key players in government's programme of action for social cohesion, creation of sustainable jobs and ensuring social and economic development'. ${ }^{28}$ In these policy documents, culture and heritage appear as untapped, imperishable resources, which Africans are particularly well positioned to utilize.

As a response to this push, cities large and small have begun 'creative' initiatives meant to place culture and heritage at the centre of urban branding and inclusive economic development. ${ }^{29}$ Johannesburg's Newtown Cultural Precinct, for instance, was heavily supported by municipal authorities and private partnerships to ensure that Newtown becomes the creative capital of Johannesburg and South Africa: dynamic, vibrant, sophisticated, and cosmopolitan, boasting the best cultural offering in Africa. ${ }^{30}$ In Cape Town, the Baxter Theatre instituted the Zabalaza Festival as a means of providing mentorship, skills development and access to the mainstream arts marketplace for township theatre-makers. ${ }^{31}$ Grahamstown too has embarked on a Creative City initiative in order to leverage existing infrastructure in place to host the NAF into year-round initiatives to foster the artistic development of its populace, and the economic development seen to go hand in hand. ${ }^{32}$

But it is important to understand that the theory and tools developed to harness the power of CCIs are not neutral. As Tim Edensor et al. have pointed out, existing theorizing on the creative economy, particularly the work of Richard Florida (whose argument that civic investment in creativity and culture leads to ongoing rates of economic growth serves as an almost reflexive citation in the SACO research that guides NAF decision making) relies on a circumscribed conception of creativity that favours established cultural activities whose products can be easily commodified by the societal mainstream. ${ }^{33}$ It alternately marginalizes, appropriates or renders invisible cultural forms (and people) that work in different aesthetic registers. ${ }^{34}$ Seen thus, CCIs not only lack the social inclusivity and egalitarianism that their advocates project, but they also allow creativity itself to become a 'discursive weapon [that] further problematize[s] non-middle-class values and peoples'. ${ }^{35}$

While creativity offers avenues for urban revitalization, it concurrently offers ways for institutions to insinuate control over public spaces, and to manage civic identity in accordance with their own institutional prerogatives. For example, the NAF itself plays a significant role in managing Grahamstown's Creative City project, just as it sponsors the Fingo Festival, seeing both as logical extensions of its own organizational 
ambitions. This expansive understanding of the festival's identity is tied up in its increased necessity to be seen as an ongoing and year-round source of economic development in order to secure subsidies and sponsors. It allows the NAF to position itself as the institutional bedrock of its city and region, and to exercise a degree of control in areas like civic branding, the location of vitalization efforts (such as choosing sites for new murals and art exhibits) and the selection of particular artistic skills to be promoted in schools. Longitudinal investment throughout Grahamstown allows the NAF to become a local mainstay, an organization that is, perhaps, 'too big to fail' since it helps secure outside investment in the area. ${ }^{36}$

The NAF's outsized role in Grahamstown's economy gives the event leverage to extract concessions from the municipality. Consider, for instance, the 2016 open letter published by Tony Lankester, provocatively titled 'Grahamstown, We Have a Problem'. Lankester begins by deploying data from a recent economic-impact study to indicate the NAF's centrality to Grahamstown's economy and symbolic prestige:

We know how money churns through the province at this time. At last count R340-million gets spent in the Eastern Cape because of the Festival, R9o-million of that in Grahamstown. It's not the biggest industry in town - education or agriculture probably hold that title - but it's the one that puts Grahamstown firmly in the public consciousness, generating over R10o-million worth of media coverage from the 500 journalists who get accreditation to cover the event. Hours and hours of television and radio coverage, hundreds of thousands of words, 'likes' and 'shares'. ${ }^{37}$

Next, he pivots to the difficult problem of the city's erratic water supply (which disrupted that year's festival, causing shortages and outages city-wide), and delivers a not-so-subtle quid pro quo to the municipality:

One set of choices [fixing the city's water infrastructure] will see, in ten years['] time, a flourishing festival that has grown steadily and confidently, and continues to be an amazing, globally recognised artistic platform and driver of the local economy. Alternatively, if we do nothing, we will have a festival that has decayed and shrivelled to a shadow of its present self. If it exists at all ... [U]nless the decline in infrastructure is halted and turned around, it is entirely feasible that the festival will not be Grahamstown in 10 years $[$ sic $]$ time. ${ }^{38}$

Lankester here positions the NAF as at once rooted in and integral to the city of Grahamstown, but also mobile, should conditions turn sour. While it articulates the entire municipality's (and even the province's) stakeholdership in the event, it implicitly prioritizes a more insular set of actors who do not remain tethered to a particular location. Thus it enunciates the community more as a form of infrastructural support than as a political commitment. ${ }^{39}$

South Africa's turn to festivals over the last quarter-century as a means of redressing apartheid's legacy of structural racism and inequality relies on framing creativity as a uniquely inclusive form of productivity that is both sustainable and measurably impactful. But the NAF's festino-centric approach, and the spatial divide in Grahamstown that flows from it, demonstrates how particular aesthetic regimes form 
the conceptual terrain of 'creativity' to the exclusion of alternative registers of cultural activity. There are, for instance, myriad avenues of festival participation that evade the statistical forms of visibility addressed through audience surveys, ticketing information or business receipts construed as data that is sufficiently 'hard' for SACO to use in its economic analyses. These forms of labour exist interstitially, as part of what Edensor et al. refer to as 'spaces of vernacular creativity', peripheral to the main proceedings, but nonetheless impactful on the event's mood and bustle. ${ }^{40}$ Performances that have historically existed on the streets of Grahamstown, enacted by tourists and Rhini residents alike, provide an important counterbalance to the statistical forms of patronage that guide organizational decision making, and these performances have provided intangible qualities crucial to building the NAF's creative value.

\section{Creating the festive vibe: a history of street performance at Grahamstown}

In 1994, a critic for the journal Contemporary Theatre Review remarked, 'From the moment one sets foot in Grahamstown, one is struck by the enormity of it all. The claustrophobic concentration of people and vehicles in a limited space, the constant, frenetic ebb and flow of people, the posters, the beggars, the clogged traffic, all add to the atmosphere. ${ }^{41}$ Curiously, perhaps, for this reviewer it was not at all the NAF's shows that appeared as the most exciting elements in Grahamstown. It was the overall feel of the space - its aesthetic - which created a sense of complete immersion and total spectacle. In this case, it is precisely the peripheral users of the NAF (even the beggars) who 'add to the atmosphere'. They endow the streets of Grahamstown with an infectious vibe, even if they do not perfectly intersect with the traditional art disciplines that make up the festival's programme.

'Vibe' - a colloquialism for vibration - has been and continues to be familiar shorthand for articulating the immaterial dimension of festival creativity in Grahamstown - in academic, journalistic and social contexts. ${ }^{42}$ Vibe is a mysterious atmospheric quality that people feel 'simmer[ing] just underneath the cultural layer of the official Festival', attracting patrons to certain places - and the artists, traders and businesses that inhabit them - while discouraging them from others. ${ }^{43}$ Vibe articulates a place's feel. It may be discussed in terms of subjective experience ('this place has a good/bad vibe'), or as an abstract positive quality that reflects a triangulation of sociality, excitement and fun - for instance, a leaflet circulated at the 2017 NAF asked participants, 'Has Grahamstown lost the Vibe?"44 In a 2018 news article, artist and festival regular Mark Rose-Christie explicitly tied a declining sense of vibe to the loss of street life in Grahamstown: 'The vibe is down, there are no street performers up on High Street to create the market feel in the environment'. ${ }^{45}$ His comment seems to reverse the festino-centric logic, projecting that an animated street life fuels festival attendance, not the other way around. Although decades of economic analyses have attempted to understand the structures and logics underpinning financial circulation prompted by the NAF, the crucial dimension of vibe remains elusive. Research on Grahamstown routinely understates or completely omits the role 
played by participants (especially Rhini residents) who may never actually enter a theatre or gallery. Their labour gets positioned as an 'externality', a peripheral activity whose fate will be decided by the managerial decisions of the centre.

By examining the history of street performance at the NAF, and challenging ourselves to maintain a broad understanding of 'performance' that can encompass activities that fall outside the festival's officially sanctioned artistic disciplines, we can visualize how institutional strategies that were developed to service the staged world of the NAF have simultaneously curated the life of Grahamstown's streets. Here I trace a brief history of street performance at the NAF since 1994. I combine archival research chronicling the festival's day-to-day activities (primarily amassed through Cue magazine, the Rhodes University publication that chronicles the NAF's daily happenings) with oral history conducted during three research trips to Grahamstown during festival time $(2014,2015,2017)$ to describe how street performances have been policed, controlled and appropriated according to the prerogatives of festival organizers since the end of apartheid.

Archival sources describing the goings-on at the NAF (from Cue's daily event reporting and festival reviews in academic journals to organizational press releases and news clippings based on those releases) tend to reiterate a festino-centric approach by concentrating the bulk of coverage on events of the stage, with action of the streets visible only in brief glimpses by reading between the lines. Thus searching for a history of the streets at the NAF necessitated taking the archive's image of the festival with 'a grain of salt'. As Premesh Lalu (working through Marx) has put it, reading the archive with 'a grain of salt' necessitates a deconstructive approach that simultaneously calls attention to the subjectivizing power of archival discourse. ${ }^{46}$ In this case, NAF coverage has tended to naturalize the sense that the world of the stage is the only significant arena of activity that takes place at the festival; this reinforces an aesthetic fault line that characterizes people on the streets as occupying the sidelines, filling in the cracks, standing adjacent to the event's main action. In contrast, here I call attention to street activities as creative labour that - like Cape Mongo - constructed ephemeral forms of infectious kinetic activity that built the NAF's jovial and inclusive vibe.

After South Africa's transition to democracy the ANC lifted its cultural boycott, and the NAF became far more festive and inclusive, with the sidewalks of High Street becoming a dense melting pot of talented locals and tourists. These early years after the institution of democracy are generally remembered as the festival's heyday. Not only were its attendance figures significantly higher, but its dense, frenzied creative atmosphere became a draw for the young and hip, who often came to town simply for the sake of taking part in the spectacle, rather than attending curated offerings. Busking, groups performing Zulu dances, crowds of young men singing 'Shosholoza', drum circles, block parties and late-night DJ-ing, fire spinning, and children performing the Māori haka, emblematized Grahamstown's streets as an idealized space of cultural integration, where middle-class festinos could interact with hippies, Rastas, vendors from all over and local talent. ${ }^{47}$ 
The excitement of this freewheeling ambience soon gave way to mandates favouring securitization and tighter management of informal trading areas. Beginning in 1997, local newspapers annually announced an increased police presence operating during the festival. That year, the festival also organized the Village Green (which, at the time, was located just down the street from Church Square, facilitating easy cross-traffic and cultural mixing) as a selected/criteria-based trading hub that catered primarily to out-of-town vendors who could afford to purchase a secure stall. Until that point, space was allotted on an ad hoc basis, creating the possibility for even those without funds to jockey for position. With the change, most local traders were pushed to Church Square, which acquired the nickname 'Bargain Village'. When Village Green became a rented space it impacted not only Grahamstonians, but also travelling contingents of hippies and Rastafarians whose presence at the festival throughout the mid-1990s was an important source of cross-racial interaction, creative street culture and social activism.

A 1998 article joked that drug culture had 'become a leading artistic discipline' in Grahamstown, but its ironic tone regarding the conflation of 'art' and drug culture exhibits the kind of aesthetic bifurcation that began to take hold at this time. ${ }^{48}$ The encampments of hippies and Rastafarians - who saw smoking ganja as an important aesthetico-philosophical component to their creative capacities - were seen as expendable $v i s-\grave{a}$-vis the event's staged offerings and paying vendors, even though the all-night drum circles and psychedelic art making in their communal tents were important parts of Grahamstown's street life. The rents required for the Village Green and a strong narcotics police presence heavily clamped down on this axis of street culture. This crackdown on drug culture impacted tourists and locals alike, with police conducting pre-festival blitzes in the townships to take dealers (who were likely stocking up for the incoming festival market) off the streets.

The new policies had a significant impact on the informal social communities that had made the NAF an all-day-all-night affair. Scuffles with police, the loss of prime event real estate and the implementation of noise ordinances that impeded overnight drum circles led large hippie and Rastafarian contingents to stop participating in the NAF. $^{49}$ Some Rastafarian communities still come, but they are now subjected to aggression by police and immigration officials, and often try to maintain a low profile. ${ }^{50}$ Simultaneously, new parking rules aimed at 'ensuring a higher turnover in available parking close to the Village Green for the Festival visitor' forced an end to late-night parties on Bathurst Street. ${ }^{51}$ For many, there was a sense that the sudden implementation of 'excessive rules' was hurting the festival's carnival atmosphere; one trader feared that overregulation would sap the NAF of its mercurial vibe: 'the wilderness of the Grahamstown Festival is going to die'. ${ }^{52}$ The Village Green was transformed from a 'freak's paradise' into a 'Mecca for the young and hip'. ${ }^{53}$ Many of those who were most intertwined with popularizing the NAF by building its vibe in the mid-1990s suddenly found themselves on the outside looking in. Noted Rastafarian Zebulon Dread (Elliot Josephs), who was part of the hippie contingent and known for distributing his satirical newsletter Hei Voetsek (Get Outta Here) at 
the festival announced that 1999 would be his last year attending the NAF since it had become 'too regimented' and had 'lost much of its spunk and verve'. ${ }^{54}$

The selective expulsion or withering away of certain street traditions served to steadily assert the primacy of officially designated venues and trading sites, rather than ad hoc spaces of vernacular creativity. This was a notable and racialized shift, since street creativity was an especially important way for poor black residents to participate in the festival using the limited means available to them. While organizers saw these activities as ancillary to the NAF's main programme - and, indeed, a potential threat should they grow out of control - local Grahamstonians perceived themselves as participating in aesthetic production: a basket weaver identified as Mrs Dlamini outlined how 'her main aim was not to make money at the festival, but to promote creativity'; local marijuana merchant Bra Mandingo discussed how he contributed to the party atmosphere by keeping his prices low despite outsiders selling at hugely inflated prices; the Bravehearts Street Dancers suggested that 'the entertainment we offer to passers-by will remind them to come back every year'. ${ }^{5}$.

Rhini residents may have only rarely taken part in the festival proper (events of the kind that get space in the NAF's official programme or get surveyed for economic analyses), but their labour was integral to enabling the enterprise. Often, this labour was provided for free, or undercompensated; it was enacted as part of an ethical imperative to build a festive atmosphere, not simply for financial gain. Interviews with Rhini artists active during these years revealed that they viewed enthusiastic festival participation in a newly open Grahamstown to be intertwined with a political commitment to rebuilding a democratic nation in the wake of apartheid. ${ }^{56}$ Decisions on how to curate event space made over time by the NAF, in conjunction with those it saw as its major stakeholders (local businesses, paying patrons, and select artists), created obstacles to participation that led to the expulsion of many of those who had provided their own, idiosyncratic means of event sponsorship. Through securitization and selective curation, the NAF was able to expand and profit; in the process it installed tacit but tangible social divisions.

Grahamstown's street mime tradition, an iconic street performance genre in today's NAF, demonstrates how these dynamics have continued to play out in recent years. Teams of boys and girls with white-painted faces, usually between five and twelve years old, stand perfectly still on street corners and outside shops all along Grahamstown's main thoroughfares. These human statues wait for passers-by to throw a coin into a hat or cardboard box that sits at their feet; if they do so, they will be rewarded with a few seconds of skipping, shuffling, pop-locking or dancing the Boogaloo before the children return to their frozen poses. Most of the mimes hope to earn enough in a day to buy a warm meal.

Child street performers like these have been present in various forms at the festival since the early 1990s, and have consistently been the subject of debate by organizers and patrons. In 1996, a member of the Bravehearts Street Dancers from Joza expressed his frustration that people viewed them as beggars, urging patrons to instead see them as 'people with vision and the ambition to become real performers'. ${ }^{57}$ His understanding of the chasm between the performer's 'realness' and the beggar's 'fakeness' alludes to 
the precarious position that street artists occupy within festival space - at the aesthetic fault line, the border between performer and panhandler. The performer may be seen as a productive member of the festival community, as a kind of site-specific event that contributes to the festive vibe by saturating the Grahamstown cityscape with creative practice. The panhandler, in contrast, is a pariah who breaks apart the festival's unified aesthetic. She fractures the seamlessness with which the NAF appears to mesh with the Grahamstown cityscape, dispelling any illusion that the festival might provide an economically sustainable and culturally inclusive counterweight to the social realities of neo-liberal South Africa.

Street mimes do not wish to be seen as beggars, but neither do they want their positionality to be completely invisible. Their physical performance - remaining quiet and frozen until someone tosses them a coin - scripts a disciplined, docile body that appears to fit right into the festivalscape. They are tolerated precisely because they exist as a kind of aestheticized beggar; they rely on piquing the generosity of arts patrons by activating a feeling of mutuality, the sense that they too are invested in the NAF's success and stand to benefit from its smooth running. Consequently, the mimes have not been policed away from Grahamstown's streets, but selectively appropriated by the event. From 2012-14, the NAF ran a programme called Art Factory that taught local youths how to perform as mimes (which they had already been doing for several years, passing repertoires down between siblings). Former festival director Ismail Mohamed sponsored the programme to help the children professionalize their work so they would stand to make more money during the event, but also to simply 'make the festival more festive, [so that whatever the children did looked like art'. ${ }^{58}$ Using prominent festival performers as teaching artists (particularly those trained in the Rhodes University Drama Department), Art Factory hewed youths into part of the NAF's overall aesthetic aims and professional protocols.

Thus street mimes were granted temporary access to stakeholdership in the NAF, which was rewarded with material resources, recognition by established artists with more secure cultural footing, and a form of legitimation that came from institutional backing. However, Art Factory ran only for three years; funding was ended when the Rhodes University student appointed to provide administrative support failed to submit an annual report on the group's finances. Street mimes continue to train in Rhini for each year's festival, as do cultural dancers, dramatic artists, circus performers and other talented individuals. Those with whom I conversed still see themselves as very much a part of the annual festival culture, but they remain confined to interstitial spaces, toeing the aesthetic fault line.

\section{Conclusions}

In the middle of the $2017 \mathrm{NAF}$, organizers unexpectedly announced that in 2018 the Village Green would move to the Victoria Girls Primary School, closer to the east side of town. It was a reaction to an overwhelming sentiment among curated traders that the festival had lost its 'vibe' and complaints from Rhini residents that the event had grown too exclusive. The year's underwhelming patron numbers may also have 
contributed to the decision. ${ }^{59}$ The day after the move was announced, several white traders - long-term fixtures in the Village Green - held a meeting to record a response to the announcement, which they addressed to festival management. Although they regarded the Village Green's move as a positive development, one that might encourage the kind of cross-city traffic and racial mixing still remembered from the mid-1990s, they pointed out that location alone could not fix the NAF's problems. Instead, they called for the festival to reassert Grahamstown's 'festive vibe' by 'invest [ing] in street people' and 'allow[ing] free, informal vending on High Street', so that informal, unpredictable local street activities could bleed effortlessly into the curated trading areas. 'People [are] afraid of crime and competition', someone argued, 'but to police it creates a sterile environment. ${ }^{60}$ In other words, it was precisely those who occupied the margins of festival space, whose presence was carefully managed by festival organizers over the years to curate a desired aesthetic for the city during festival time, and whose immaterial labour has generally evaded economic analyses, who were seen as primarily responsible for the success of one of the NAF's core constituencies.

The traders viewed the new move with a sense of optimism, believing that shifting the Village Green eastward could bring those who had been expelled from the event back into the fold. However, a Joza artist named Thembelani, who was also present, seemed less optimistic. He saw the primary school, like Rhodes, as a 'white space', its large walls and colonial architecture marking the kind of gentility that alienated township residents, reminding them that the festival's very structure was designed with certain people in mind. Furthermore, he predicted that moving the Village Green towards the centre of town might also necessitate increased security in that part of town, further expanding the areas where township residents might feel surveilled and subtly discouraged from entering. Despite what appeared as a geographically inclusionary gesture, Thembelani anticipated the fresh installation of new aesthetic fault lines. He preferred that the Village Green move back to its original location on Fiddler's Green, its 1990 os and early 2000 s location just down the street from Church Square. In a lengthy newspaper article reviewing the 2017 festival, Tony Lankester acknowledged the validity of Thembelani's point of view ('Yes, the 'back to Fiddlers' argument is loud and passionate'), but he nonetheless advocated 'giving something new a chance before deciding it's a bad idea'. He pointed to the formation of 'committees comprising local business, traders and ordinary Festinos' to develop ideas for the new space. ${ }^{61}$ But absent from his discussion was an articulation of who constituted an 'ordinary Festino' - those who viewed the festival as an event of the stage or of the street?

In 2018, the first year with the new festival layout, the NAF reported a 4.5 per cent increase in box office receipts, an increase that new executive producer Ashraf Johaardien attributed in part to the revamping of the Village Green. He stated, 'box office figures are by no means a comprehensive measure when it comes to the role, purpose - or indeed story of the National Arts Festival - but they are nevertheless an important key indicator of performance in a given year'. ${ }^{62}$ This is precisely a continuation of the festino-centric approach: box office figures, while acknowledged to be insufficient measures of event success, nonetheless get publicized to demonstrate the utility of new initiatives; the opinions and experiences of local traders 
and street artists, which cannot easily be translated into statistics, are omitted from the journalistic record.

I suggest that, despite an increase in attendance, the ultimate success of the Village Green's move remains unclear. What is obvious is that the efficacy of festivals as key components in the broader push towards CCIs as means of building sustainable and inclusive futures in South Africa relies on spatial politics that cannot be fully accounted for by models of cultural patronage tethered solely to artistic disciplines of the stage. The example of the NAF illustrates the necessity for theoretical models that can remain attentive to the qualitative dimension of the street, the ad hoc, combinative, interpersonal modes of effervescence responsible for truly submerging citizens in a festive atmosphere. Concretely, this means that, rather than emphasize a singular bottom line of economic impact, festival research conducted by organizations like SACO should be challenged to develop intricate approaches that can account for variegated spatial and demographic segmentation in the places they study. As the NAF continues to propel Grahamstown's economy, questions of aesthetics will continue to drive which bodies can (and cannot) be recognized as having the vision to help organize a collective future, and which repertoires will (and will not) be understood to belong to that future.

NOTES

$1 \quad$ Funding for my field work was made possible through grants from the University of Minnesota's Graduate Research Partnership Program and a Targeted Area Research Grant from the American Society for Theatre Research. I would like to thank the staff of the National English Literature Museum (NELM) in Grahamstown for their incredible assistance in the archival research for this article, especially Petro Nhlapo. Early versions of this article were delivered to the 2016 International African Studies Conference at the University of Minnesota, where I received very helpful feedback. This work would not have been possible without feedback and assistance from Jessica Farrell, Virgil Slade, Paul Vig, George Agbo, Aidan Erasmus, Lauren van der Rede, Helena Pohlandt-McCormick, Kellen Hoxworth, Megan Lewis, Gibson Cima, April Sizemore-Barber, Margaret Werry and Sarah Saddler.

South African Cultural Observatory, 'Key Development Indicator Report on DAC Interventions', South Africa Department of Arts and Culture (2017). 'No to Arts Hypermarket', Cue, 14 July 1995, p. 7.

4 Francois Knoetze, at https://francoisknoetze.carbonmade.com/about, accessed 15 October 2018. Author's interview with Francois Knoetze, e-mail, 18 January 2017.

$5 \quad$ Ibid.; Cue, 4 July 2013, p. 8.

6 In South Africa, 'coloured' is a legislated racial identity that indicates mixed-race individuals. It should also be noted that several Village Green slots are subsidized and reserved for non-white Eastern Cape vendors who could not otherwise afford to participate.

$7 \quad$ Cue, 4 July 2013, p. 8.

8 Author's interview with Francois Knoetze, e-mail, 18 January 2017. Parentheses included in author's response.

9 In addition to myriad academic articles discussing the NAF in Performing Arts Journal and South African Theatre Journal, Theatre Journal has published review articles of the festivals nearly annually since 2006. For an indicative selection of festival reviews in scholarly journals see Louis Pretorius and Mareli Pretorius: 'There and Back Again: The National Arts Festival, Grahamstown [report]', South African Theatre Journal, 20 (2006), pp. 263-9; Hannah Borthwick, "World Cup of the Arts" - The Grahamstown National Arts Festival 2010 - An Overview [report]', South African Theatre Journal, 25, 1 
(March 2011), p. 78(9); Megan Lewis, 'Past, Present, and Future: A Tense South Africa Performs [review]', PAJ: A Journal of Performance and Art, 30, 2 (May 2008), pp. 93-101. April Sizemore-Barber, 'South Africa's National Arts Festival (review)', Theatre Journal, 65, 2 (May 2013), pp. 261-4.

Abraham G. van der Vyver and Franzél du Plooy-Cilliers, 'The Social Dynamics of Arts Festivals: A Comparative Analysis of the KKNK and the Grahamstown National Arts Festival', South African Theatre Journal, 20 (2006), pp. 192-203.

'Aesthetic', OED Online, July 2018, Oxford University Press, at www.oed.com.ezp.lib.unimelb.edu.au/ view/Entry/3237? result=1\&rskey=t7kDrv\&, accessed 31 October 2018. South Africa Department of Arts and Culture, '1996 White Paper on Arts, Culture, and Heritage', at www.dac.gov.za/content/white-paper-arts-culture-and-heritage-o, accessed 15 October 2018; 'Revised White Paper on Arts, Culture, and Heritage Fourth Draft' (2017), at www.dac.gov.za/content/revisedwhite-paper-arts-culture-and-heritage-fourth-draft-o, accessed 15 October 2018.

13 The same article notes that the NAF quickly changed its Facebook name to 'National Arts Festival Makhanda'; however, at the time of publication, the NAF's homepage still notes that the event 'is held in the small university city of Grahamstown'. Sue Maclennon, 'Festival Quick off Makhanda Mark', 10 July 2018, National Arts Festival, at www.nationalartsfestival.co.za, accessed 15 October 2018.

14 In Apartheid's Festival: Contesting South Africa's National Pasts (Bloomington: Indiana University Press, 2003), for instance, Leslie Witz explicates how events like the Jan van Riebeeck Tercentenery Festival operated as participatory means to create attachments to white supremacist historical myths perpetuated by segregationist ideology. For further information on the importance of festivals in the representation of South African identity during and after apartheid see Sabine Marshall, 'Creating the "Rainbow Nation": The National Women's Art Festival in Durban, South Africa', in David Picard and Mike Robinson, eds., Festivals, Tourism and Social Change: Remaking Worlds (Bristol: Channel View Publications, 2006), pp. 152-71; Temple Hauptflesich, 'Eventifying Identity: Festivals in South Africa and the Search for Cultural Identity', New Theatre Quarterly, 22, 2 (2006), pp. 181-98.

15 Kenneth W. Grundy, 'The Politics of South Africa's National Arts Festival: Small Engagements in the Bigger Campaign', African Affairs, 93 (1994), pp. 387-409, here p. 397.

16 'Speech by President Nelson Mandela at the re-dedication of the 1820 settlers monument Grahamstown', 16 May, 1996, South African History Online, at www.sahistory.org.za/archive/speech-president-nelsonmandela-re-dedication-1820-settlers-monument-grahamstown-16-may-1996, accessed 15 October 2018. See, for example, David Harvey, 'Neoliberalism as Creative Destruction', Annals of the American Academy of Political and Social Science, 610 (March 2007), pp. 22-44.

18 National Arts Festival, 'Standard Bank Ensures the Festival Moves Forward', at /www.nationalartsfestival. co.za/news/standardbank-sponsorship-2020, accessed 15 October 2018; South Africa Department of Arts and Culture, 'Arts and Culture Sponsors the 2016 National Arts Festival', at www.dac.gov.za/content/ arts-and-culture-sponsors-2016-national-arts-festival, accessed 15 October 2018.

19 South African Cultural Observatory, 'National Research Agenda', 2017, at www. southafricanculturalobservatory.co.za/national-research-agenda, accessed 31 October 2018. Jennifer Snowball, 'A Framework for the Monitoring and Evaluation of Publically Funded Arts, Culture, and Heritage', South African Cultural Observatory, 2016, pp. 8-15.

20 The Fingo Festival's official slogan is 'Be Part of Greatness'. Fingo Festival, at www.facebook.com/pg/ FingoFestival/about/?ref=page_internal, accessed 15 October 2018.

21 Zaza Hlalethwa, 'What Happens after the Fest', Mail \& Guardian, 13 July 2018, at https://mg.co.za/article/ 2018-07-13-00-what-happens-after-the-fest, accessed 25 October 2018.

22 Author's interview with Vuyo Booi, 26 June 2017; author's interview with Thembelani Polose, 8 July 2017; author's interview with Sweli (no last name given), 5 July 2017. An article for the Press Reader demonstrates how the NAF's sponsorship of the Fingo Festival became a talking point: 'In 2012, the Fingo Fest was integrated into the main programme of the NAF to affirm the fellowship between the townships and suburban areas[.] Tony Lankester, the NAF's chief executive, said the festival was open to partnering 
with the community: 'We have launched, together with the Fingo Festival, a whole initiative in Fingo Village. We put out a Coca-Cola truck and gave them some cash $[$ R65,00o], because they came to us with a great idea'. Hlalethwa, 'What Happens after the Fest?'.

23 Some landmarks include the gravesites of King Lobengula's son (who was taken prisoner and renamed 'Rhodes' Lobengula by infamous colonist and diamond baron Cecil John Rhodes in 1893) and grandson, and the Fingo home where Rhodes Lobengula's family settled. The latter is currently being converted into an 'African museum to reflect the history and culture of the Lobengula Family and the early settlers of Fingo Village'. Plans are also under way, led by Sizwe Mda (grandson of Rhodes Lobengula), Nomso Mda and the King Lobengula Foundation, to erect a massive cross on Makana's Kop in the style of Rio de Janeiro's Christ the Redeemer. Grocott's Mail, 4 October 2013, at afrihost.grocotts.co.za/content/opinion/ letters/lobengula-heritage-grahamstown-07-10-2013, accessed 17 December 2018, n.p.; author's interview with Sizwe Mda, 27 June 2017. Author's field notes, 6 July 2017.

25 Author's field notes, 6 July 2017.

26 African Union, Charter for African Cultural Renaissance (2006), at https://au.int/en/treaties/charterafrican-cultural-renaissance, accessed 15 October 2018, p. 7, emphasis added.

27 Ibid., p. 8.

28 Department of Arts and Culture, Mzansi Golden Economy (MGE) Guidelines: Criteria, Eligibility, Processes and Systems, Republic of South Africa, Version 1.0.5 (2016-17), p. 5.

29 Kevin Mearns, 'Newtown Cultural Precinct Driving Tourism Led Urban Regeneration within the Johannesburg Inner-City', African Journal of Hospitality, Tourism and Leisure, 3 (2014), pp. 1-10, here p. 2.

$30 \quad$ Blue IQ, Annual Report, Gauteng Province (2012), p. 47.

31 Gay Morris, 'Dinosaurs Become Birds: Changing Cultural Values in Cape Town Theatre', Theatre Research International, 42, 2 (2017), pp. 146-62.

32 National Arts Festival, 'Creative City Grahamstown', 2014, at www.creativecity.co.za, accessed 31 October 2018.

33 Florida argues that cities should invest in creativity and culture to attract 'talent' (often through utilizing the infrastructure of local universities); over time, the presence of this 'talent' leads to a 'virtuous circle' characterized by 'higher rates [of] economic growth[,] more job generation and in turn [h]igher rates of talent production, retention and attraction'. Richard Florida, Gary Gates, Brian Kundsen and Kevin Stolarick, 'The University and the Creative Economy', The Creative Class Group, George Mason University, Carnegie Mellon and UCLA (2006), p. 30.

34 Tim Edensor, Deborah Leslie, Steve Millington and Norma M. Rantisi, 'Rethinking Creativity: Critiquing the Creative Class Thesis', in Edensor, Leslie, Millington and Rantisi, eds., Spaces of Vernacular Creativity: Rethinking the Cultural Economy (New York: Routledge, 2009), pp. 1-16.

35 Ibid., p. 7.

36 The Creative City project has secured significant outside investment from the European Union, as well as from ASSITEJ South Africa; Kuns Onbeperk; Makana Municipality; Cacadu District Municipality; the Eastern Cape Department of Sports, Recreation, Arts and Culture; Sarah Baartman District Municipality; Rhodes University; the Grahamstown Chamber of Commerce; Makana Tourism; and Assumption Development Centre.

37 Grocott's Mail, 16 July 2016, n.p.

38 Ibid.

39 Recently, Lankester reiterated this position, saying, 'When I am asked [if the festival is staying in Grahamstown] I reply: "We will stay in Grahamstown as long as it is capable of hosting us". And it is becoming increasingly difficult to justify'. Adrienne Carlisle, 'Decaying Grahamstown "Could Lose Arts Festival”', Herald Live, 5 May 2018, at www.heraldlive.co.za/weekend-post/your-weekend/2018-05-05decaying-grahamstown-could-lose-arts-festival, accessed 15 October 2018. 
$40 \quad$ Edensor et al., pp. 10-16.

41 Dudley Peterson, 'Patterns of Change: Audience, Attendance, and Music at the 1994 Grahamstown Festival', Contemporary Theatre Review, 9, 2 (1999), pp. 61-70, here p. 62. See, for instance, Van der Vyver and du Plooy-Cilliers, 'The Social Dynamics of Arts Festivals', 199; Zodidi Dano, 'National Arts Fest Fever Wanes', Cape Argus, 4 July 2018, p. 5.

43 Cue, 3 July 1998, p. 7.

44 Author's field notes, 8 July 2017.

45 Cape Argus, 4 July 2018, p. 5.

46 Lalu draws on Marx's writing in 'The German Ideology' and The Grundrisse. Premesh Lalu, The Deaths of Hintsa: Postapartheid South Africa and the Shape of Recurring Pasts (Cape Town: HSRC Press, 2009), pp. 101-40.

47 Sometimes referred to as South Africa's second national anthem, 'Shosholoza' is a call-and-response song traditionally sung by mixed groups of Ndebele and Zulu miners. The song also has a resonance as part of the anti-apartheid struggle, with Nelson Mandela reporting to have sung it while labouring during his imprisonment on Robben Island from 1962 to 1990. City Press, 8 July 1994, p. 3.

48 Cue, 8 July 1998, p. 8.

49 Discussions with a group of former participants in the NAF's hippie community first surfaced these reasons for their disengagement with the festival. I was able to largely corroborate their account thanks to the Fringe Voice, a publication by the East Cape News Agency that aimed to 'throw light on the marginalized sectors of festival and society', depicting the emerging bifurcation of NAF street life and the festival proper, as well as the securitization of Grahamstown during festival time. Fringe Voice, 4 July 1996, p. 1; author's field notes 16 July 2014.

50 Rastafarian street traders I interviewed during the 2017 festival claimed that immigration officers had targeted their stall, arresting one person when he was unable to produce identification. They presumed that registering their stall with the festival would entail some degree of institutional protection from such harassment. Author's field notes, 1 July 2017.

51 Cue, 5 July 1997, p. 9.

52 Ibid.

53 Cue, 6 July 1994, n.p.; 8 July 2000, p. 12.

54 Cue, 4 July 1999, p. 2.

55 Fringe Voice, 6-7 July 1996, p. 2.

56 Author interview with Vuyo Booi, 26 June 2017; author interview with Thembelani Polose, 8 July 2017.

57 Fringe Voice, 6-7 July 1996, p. 2, emphasis added.

58 Author's interview with Vuyo Booi, 26 June 2017.

59 Tony Lankester reported that the festival experienced a 10 per cent drop in its 2017 attendance, which he blamed primarily on South Africa's economic recession that year. He also painted an optimistic picture of the decision to move the Village Green, noting that such innovation and change are 'recession-proof, 'And that, Grahamstown, is what a recession looks like', Grocott's Mail, 14 July 2017, at https://www.grocotts.co. za/2017/07/14/and-that-grahamstown-is-what- a-recession-looks-like, accessed 17 December 2018, n.p.

$60 \quad$ Author's field notes, 8 July 2017.

61 Tony Lankester, Grocott's Mail, 14 July 2017, emphasis added.

62 'National Arts Festival Reports Positive Results for 2018 Festival', RNews, 2 August 2018, at www.rnews.co. $\mathrm{za} /$ article/21156/national-arts-festival-reports-positive-results-for-2018-festival, accessed 15 October 2018.

BRYAN SCHMIDT (schmid18@stolaf.edu) is a Visiting Instructor in the St Olaf College Theater Department, and a PhD Candidate in the University of Minnesota's Department of Theatre Arts and Dance. His dissertation is titled 'Transformational Festivals and the Enchantment Economy: Performance and Race in Neoliberal Times'. His work can be seen in TDR, Theatre Journal and Dancecult: The Journal of Electronic Dance Music Culture, as well as the volume Weekend Societies: Electronic Dance Music Festivals and Event-Cultures (2017). 